\title{
STUDI NUMERIK RESPON GETARAN MESIN BENSIN DUA SILINDER SEGARIS DENGAN VARIASI SUDUT ANTAR ENGKOL
}

\author{
Hendri Suryanto \\ Jurusan Teknik Mesin \\ Sekolah Tinggi Teknologi Ronggolawe Cepu \\ Email: hendrie_s@yahoo.com \\ Sarip \\ Jurusan Teknik Mesin \\ Sekolah Tinggi Teknologi Ronggolawe Cepu \\ Email: hidayatullohsarip566@gmail.com
}

\begin{abstract}
ABSTRAK
Getaran dari mesin (engine) adalah salah satu sumber getaran pada kendaraan. Getaran ini disebabkan adanya variasi tekanan gas di dalam silinder dan fluktuasi gaya karena gerakan berputar dan gerakan bolak-balik komponen-komponen mesin. Penelitian ini bertujuan untuk mengetahui besar getaran dan menganalisa getaran mesin empat langkah $550 \mathrm{cc}$ dua silinder segaris, dengan memvariasikan sudut antar engkol $0^{\circ}, 90^{\circ}$, dan $180^{\circ}$. Mesin ditumpu oleh tiga dudukan karet (rubber mounts) dengan posisi dua di depan dan satu di belakang. Penelitian dilakukan dengan membuat model dinamis mesin dalam lima derajat kebebasan. Gaya eksitasi yang bekerja pada mesin ditentukan dari tekanan gas hasil pembakaran dalam silinder dan gaya inersia bagian-bagian mesin yang berputar dan bergerak resiprokal. Input parameter-parameter lain dalam pemodelan ditentukan dari pengukuran bagian-bagian mesin yang terlibat dalam pemodelan, kemudian dilakukan simulasi model dengan software MATLAB Simulink untuk mengetahui respon getaran blok mesin dalam arah translasi vertikal (arah sumbu $Y$ ) pada variasi kecepatan putaran mesin 1000, 3000 dan $5000 \mathrm{rpm}$. Hasil simulasi menunjukkan getaran blok mesin terbesar terjadi pada posisi sudut antar engkol $180^{\circ}$ dan terkecil pada sudut $0^{\circ}$.
\end{abstract}

Kata kunci: mesin dua silinder, getaran, pemodelan dan dinamika mesin.

\begin{abstract}
Vibration was induced by engine is one of vibration sources that occurs in the vehicle. This vibration is caused by gas pressure variation inside the cylinder and force fluctuation from rotating and reciprocating components of engine. In this study, vibration magnitude and analysis on 550 cc four stroke two inline cylinders engine by varying angle between cranks $0^{\circ}, 90^{\circ}$, dan $180^{\circ}$ was studied. The engine was supported by three rubber mounts, two of them were mounted on front and another on rear. Modeling a five degree of freedom of engine dynamic was conducted in this study. Excitation forces exerted on the engine was obtained from gas pressure produced by combustion in cylinder and inertia forces of rotating and reciprocating components of engine. Input parameters on model was obtained from measurement of engine components involved in modeling, then model simulation using MATLAB Simulink software was conducted to find vibration response of vertically translation ( $Y$ axis direction) of engine block, at engine speed of 1000, 3000, and $5000 \mathrm{rpm}$. The simulation results showed that the highest vibration of engine occurred at $180^{\circ}$ of angle between two cylinder cranks and the smallest at $0^{\circ}$.
\end{abstract}

Keywords: two cylinders engine, vibration, modeling and engine dynamic.

\section{PENDAHULUAN}

Getaran pada kendaraan menyebabkan ketidaknyamanan berkendara. Salah satu sumbernya adalah mesin kendaraan yang merupakan jenis mesin pembakaran dalam (internal combustion engine). Kenyamanan kendaraan bergantung pada seberapa halus gerakan suatu mesin saat beroperasi dan seberapa efektif gaya getaran mesin diisolasi terhadap chassis [1].

Dua sumber utama dari getaran mesin adalah variasi dari tekanan gas di dalam silinder dan fluktuasi gaya karena bagian-bagian mesin yang berputar dan bergerak bolak-balik (reciprocating parts) [2]. Tekanan gas akibat ledakan dari campuran bahan bakar dan udara di dalam silinder yang mengenai permukaan atas piston, menghasilkan gaya gas yang akan memutar poros engkol (crank shaft) sehingga mesin menghasilkan torsi keluaran yang akan digunakan untuk menggerakkan kendaraan. Kondisi ini terjadi pada saat langkah pembakaran (combustion stroke). Sedangkan pada saat langkah kompresi 
(compression stroke) kecepatan putar poros engkol akan menurun. Perubahan kecepatan putar ini menyebabkan fluktuasi kecepatan poros engkol dan getaran torsional pada poros engkol [1]. Bagianbagian mesin yang berputar dan bergerak bolak-balik yaitu piston, connecting rod dan crank shaft menghasilkan gaya inersia yang mengakibatkan gaya tak seimbang. Gaya tak seimbang pada blok mesin terjadi karena variasi gaya inersia pada saat langkah kompresi dan pembakaran. Gaya tak seimbang pada blok mesin ini adalah sebagai getaran longitudinal dalam tiga arah orthogonal [1], sehingga pada mesin terjadi dua tipe getaran yaitu getaran torsional dan getaran longitudinal. Kedua getaran ini dapat dikurangi dengan meminimalkan gaya-gaya tak seimbang dan dengan menyangga mesin dengan dudukan-dudukan (mounts) mesin yang sesuai.

Karabulut [3] melakukan penelitian getaran dengan membuat model dinamis tiga derajat kebebasan dari mesin pembakaran dalam empat langkah dua silinder. Simulasi dilakukan dengan variasi kecepatan poros engkol, variasi torsi dan daya dengan kecepatan, getaran torsional dan translasi dari blok mesin, dan variasi gaya dudukan dengan koefisien redaman dan kekakuan dari dudukan. Penelitian lain sebelumnya, Hoffman dan Dowling [4] juga memodelkan dinamika mesin pembakaran dalam dengan perlakuan tergandeng (coupled) antara gerakan mekanisme piston-connecting rod-poros engkol dengan gerakan blok mesin. Kebanyakan pemodelan getaran mesin berdasarkan asumsi bahwa gaya-gaya tergandeng (coupling forces) antara komponen-komponen internal yang bergerak dan blok mesin adalah berdiri sendiri-sendiri dalam gerakan getar mesin. Pengaruh gesekan-gesekan yang terjadi pada komponenkomponen yang bersinggungan juga diperhitungkan dalam penelitian getaran mesin disamping pengaruh dari gaya-gaya inersia komponen-komponen mesin, seperti dalam penelitian oleh Guzzomi dkk [5], pengaruh gesekan piston dan silinder terhadap dinamika gerak blok mesin diperhitungkan dalam pemodelan dinamik yang kemudian disimulasikan. Gaya gesek dalam penelitian yang dilakukan oleh Guzzomi dkk ini juga digunakan oleh Karabulut dalam membuat model getaran mesin empat langkah dengan dua silinder segaris. Park dkk [2] melakukan penelitian untuk mengurangi eksitasi gaya dan momen pada mesin empat langkah tujuh silinder dengan mengoptimasi sudut-sudut poros engkol dimana posisi sudut-sudut poros engkolnya tidak dibagi merata (360 derajat dibagi jumlah silinder) seperti mesin segaris (in-line engine) konvensional. Penelitian pada sistem dudukan mesin (engine mounting system) yang berfungsi sebagai peredam getaran mesin juga telah dilakukan mulai dari dudukan jenis elastomer hingga hidrolik dan dari dudukan pasif hingga aktif untuk memperbaiki unjuk kerjanya, seperti yang dikemukakan dalam kajian literatur oleh Yu dkk [6]. Pada dasarnya pada mesin dengan dua silinder segaris jika kedua piston serempak bergerak ke arah yang sama maka getaran mesin semakin besar dan jika bergerak ke arah berlawanan maka getaran mesin semakin kecil. Besarnya getaran yang terjadi, dalam perancangan suatu mesin, perlu diketahui karena akan mempengaruhi performa suatu mesin. Besarnya getaran mesin dalam tahap perancangan bisa diketahui dan dianalisa dengan cara melakukan simulasi dengan suatu software.

Getaran mesin bensin dua silinder segaris empat langkah akan diteliti dalam penelitian ini. Penelitian dilakukan dengan membuat model dinamis mesin dalam satu derajat kebebasan, dengan sudut antar engkolnya dibuat $0^{\circ}, 90^{\circ}$, dan $180^{\circ}$ untuk mengetahui respon getaran translasi vertikal (arah sumbu $Y$ ). Mesin ditumpu oleh dudukan karet (rubber mounts).

\section{METODOLOGI PENELITIAN}

Model dinamis mesin dalam lima derajat kebebasan dibuat dalam penelitian ini, untuk mengetahui respon getaran blok mesin akibat gaya-gaya eksitasi. Gaya-gaya eksitasi terdiri dari gaya karena tekanan gas hasil pembakaran di dalam silinder (gaya gas) dan gaya inersia dari gerakan piston, connecting rod dan poros engkol. Persamaan gerak blok mesin diturunkan berdasarkan model dinamis mesin. Persamaan state variable dibuat berdasarkan persamaan gerak blok mesin, kemudian dibangun diagram blok dengan Simulink Matlab untuk mengetahui respon getarannya.

\subsection{Model Dinamis Mesin}

Model dinamis mesin seperti ditunjukkan gambar 1 berikut ini. 


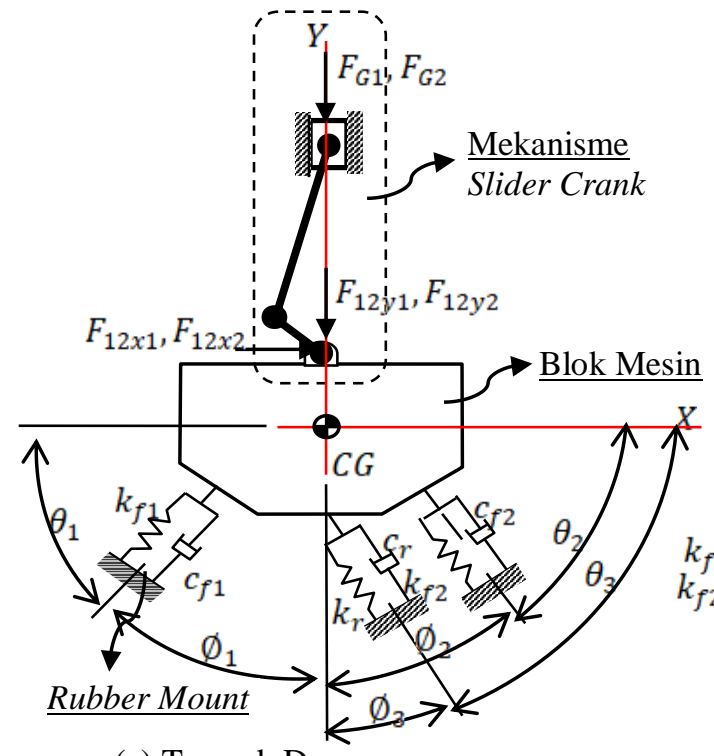

(a) Tampak Depan

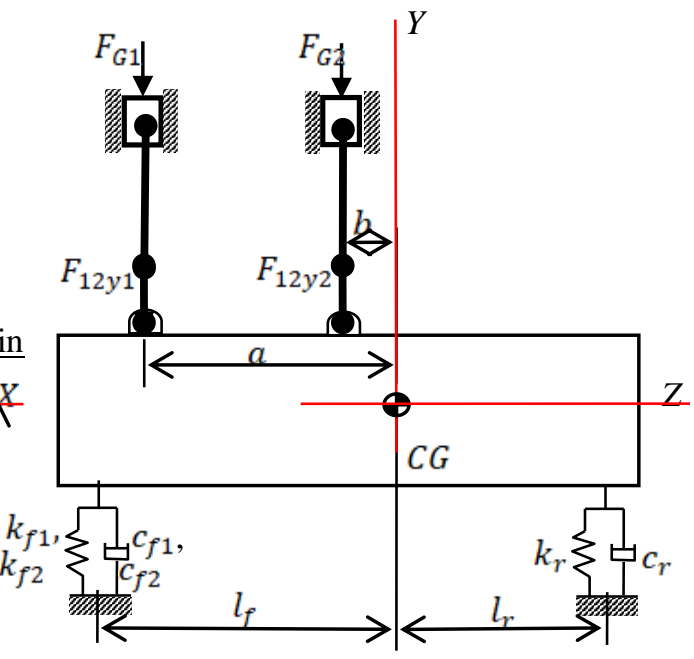

(b) Tampak Samping

\section{Gambar 1. Model Dinamis Mesin}

Gaya-gaya eksitasi pada blok mesin dihasilkan dari mekanisme slider crank yang menyebabkan gaya inersia akibat gerakan piston, connecting rod dan poros engkol. Besarnya gaya eksitasi ditentukan dari persamaan gerak dari model dinamis mekanisme slider crank pada gambar 2 . Besar $F_{14}, F_{34}, F_{12 \mathrm{y}}$, $F_{12 x}$ dan $T_{12}$ ditentukan dari persamaan (1) sebagai berikut :

$\left[\begin{array}{ccccc}-\mu & -A & 0 & 0 & 0 \\ 1 & -B & 0 & 0 & 0 \\ 0 & -C & -1 & 0 & 0 \\ 0 & -D & 0 & -1 & 0 \\ 0 & -E & 0 & 0 & 1\end{array}\right]\left\{\begin{array}{c}F_{14} \\ F_{34} \\ F_{12 y} \\ F_{12 x} \\ T_{12}\end{array}\right\}=\left\{\begin{array}{c}-F_{G}+F_{r}+m_{B} r \omega_{2}^{2}\left(\cos \omega_{2} t+\frac{r}{l} \cos 2 \omega_{2} t\right) \\ 0 \\ m_{A} r \omega_{2}^{2} \cos \omega_{2} t \\ m_{A} r \omega_{2}^{2} \sin \omega_{2} t \\ 0\end{array}\right\}$

dimana :

$A=\cos \left(\sin ^{-1} \frac{r}{l} \sin \omega_{2} t\right)$

$B=\sin \left(\sin ^{-1} \frac{r}{l} \sin \omega_{2} t\right)$

$C=\cos \left(\sin ^{-1} \frac{r}{l} \sin \omega_{2} t\right)$

$D=\sin \left(\sin ^{-1} \frac{r}{l} \sin \omega_{2} t\right)$

$E=\sin \left(\sin ^{-1} \frac{r}{l} \sin \omega_{2} t\right) r \cos \omega_{2} t-\cos \left(\sin ^{-1} \frac{r}{l} \sin \omega_{2} t\right) r \sin \omega_{2} t$

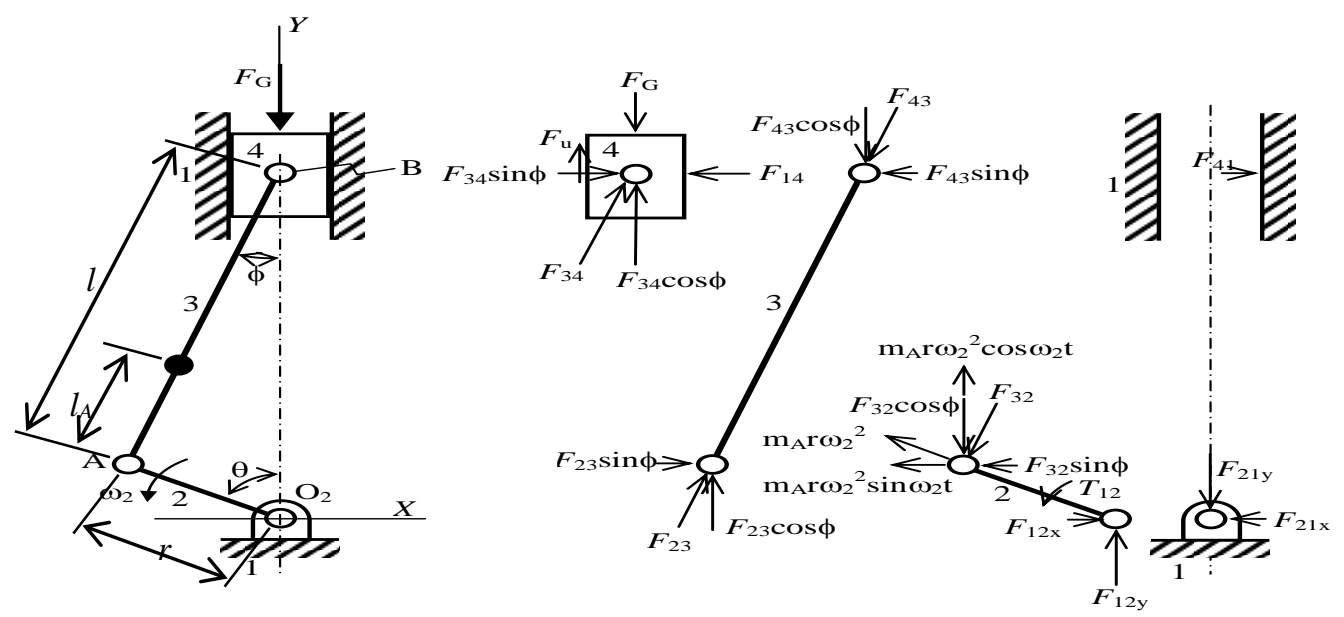

Gambar 2. Mekanisme Slider Crank Dan Diagram Benda Bebas Masing-Masing Batang Penghubung 
Persamaan gerak blok mesin diturunkan dari model dinamis mesin tersebut. Besarnya gaya pegas dan peredam ditentukan dulu dari masing-masing rubber mounts. Besar gaya pegas dan peredam ditentukan berdasarkan displacement arah Y dan X pada posisi miring terhadap sumbu vertikal maupun horisontal. Akibat displacement arah $\mathrm{Y}$ masing-masing gaya pegas dan peredam arahnya seperti ditunjukkan pada gambar 3(a), besar gaya pegas adalah $F_{k}=k y \cos \emptyset$, dan gaya peredam adalah $F_{c}=c \dot{y} \cos \emptyset$, sehingga besar gaya pegas dan peredam dalam arah $\mathrm{X}$ adalah $F_{k X}=k y \cos \emptyset \cos \theta$ dan $F_{c X}=c \dot{y} \cos \emptyset \cos \theta$, dalam arah Y adalah $F_{k Y}=k y \cos ^{2} \emptyset$ dan $F_{c Y}=c \dot{y} \cos ^{2} \emptyset$. Sedangkan akibat displacement arah $\mathrm{X}$ ditunjukkan pada gambar 3(b), besar gaya pegas adalah $F_{k}=k x \cos \theta$ dan gaya peredam adalah $F_{c}=c \dot{x} \cos \theta$, sehingga besar gaya pegas dan peredam dalam arah $\mathrm{X}$ adalah $F_{k X}=k x \cos ^{2} \theta$ dan $F_{c X}=c \dot{x} \cos ^{2} \theta$, dalam arah $\mathrm{Y}$ adalah $F_{k Y}=k x \cos \theta \cos \emptyset$ dan $F_{c Y}=c \dot{x} \cos \theta \cos \emptyset$.

Besar gaya pegas dan peredam untuk masing-masing rubber mounts dalam arah vertikal dan horisontal secara keseluruhan adalah :

a) Untuk posisi depan

$$
\begin{aligned}
& F k_{f y}=\left(k_{f 1} \cos ^{2} \emptyset_{1}+k_{f 2} \cos ^{2} \emptyset_{2}\right) y_{b}+\left(k_{1} \cos \theta_{1}+k_{2} \cos \theta_{2} \cos \emptyset_{2}\right) x_{b} \\
& F c_{f y}=\left(c_{f 1} \cos ^{2} \emptyset_{1}+c_{f 2} \cos ^{2} \emptyset_{2}\right) \dot{y}_{b}+\left(c_{f 1} \cos \theta_{1} \cos \emptyset_{1}+c_{f 2} \cos \theta_{2} \cos \emptyset_{2}\right) \dot{x}_{b} \\
& F k_{f x}=\left(k_{f 1} \cos \emptyset_{1} \cos \theta_{1}+k_{f 2} \cos \emptyset_{2} \cos \theta_{2}\right) y_{b}+\left(k_{f 1} \cos ^{2} \theta_{1}+k_{f 2} \cos ^{2} \theta_{2}\right) x_{b} \\
& F c_{f x}=\left(c_{f 1} \cos \emptyset_{1} \cos \theta_{1}+c_{f 2} \cos \emptyset_{2} \cos \theta_{2}\right) \dot{y}_{b}+\left(c_{f 1} \cos ^{2} \theta_{1}+c_{f 2} \cos ^{2} \theta_{2}\right) \dot{x}_{b}
\end{aligned}
$$

b) Untuk posisi belakang

$$
\begin{aligned}
& F k_{r y}=k_{r} y_{b} \cos ^{2} \emptyset_{3}+k_{r} x_{b} \cos \theta_{3} \cos \emptyset_{3} \\
& F c_{r y}=c_{r} \dot{y}_{b} \cos ^{2} \emptyset_{3}+c_{r} \dot{x}_{b} \cos \theta_{3} \cos \emptyset_{3} \\
& F k_{r x}=k_{r} y_{b} \cos \emptyset_{3} \cos \theta_{3}+k_{r} x_{b} \cos ^{2} \theta_{3} \\
& F c_{r x}=c_{r} \dot{y}_{b} \cos \emptyset_{3} \cos \theta_{3}+c_{r} \dot{x}_{b} \cos ^{2} \theta_{3}
\end{aligned}
$$

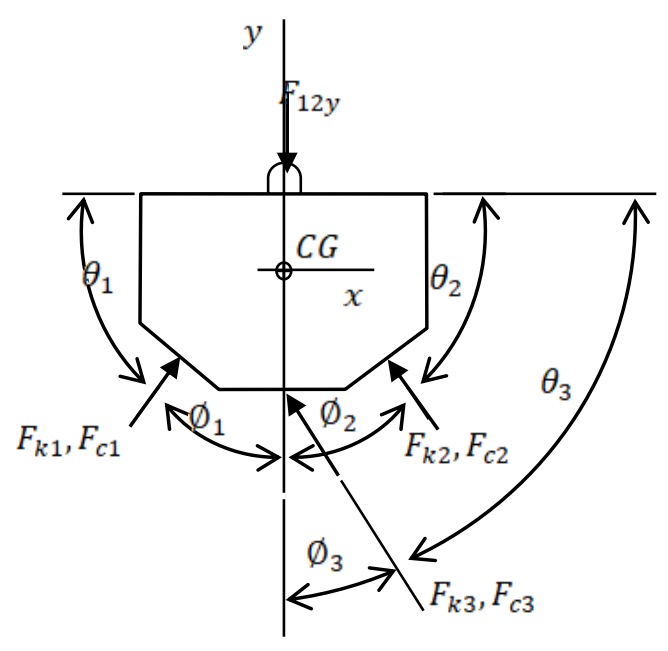

(a)

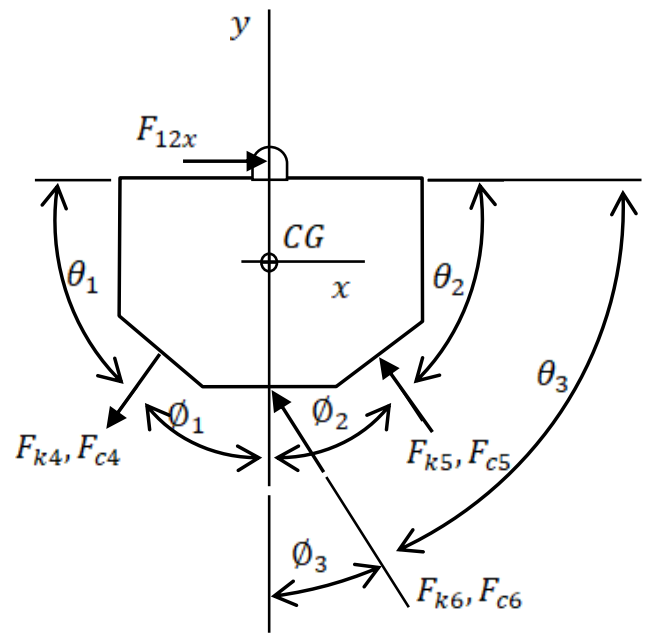

(b)

Gambar 3. (a) Gaya Pegas dan Peredam Arah Vertikal, (b) Arah Horisontal

Persamaan gerak blok mesin dalam arah vertikal (sumbu Y) diturunkan dari diagram benda bebas seperti ditunjukkan pada gambar 4. Persamaan gerak translasi vertikal blok mesin adalah :

$\sum F_{y}=m \ddot{y}_{b}$

$m \ddot{y}_{b}+\left(c_{f 1} \cos ^{2} \emptyset_{1}+c_{f 2} \cos \emptyset_{2}+c_{r} \cos ^{2} \emptyset_{3}\right) \dot{y}_{b}+\left(k_{f 1} \cos ^{2} \emptyset_{1}+k_{f 2} \cos ^{2} \emptyset_{2}+k_{r} \cos ^{2} \emptyset_{3}\right) y_{b}+$ $\left(c_{f 1} \cos \theta_{1} \cos \emptyset_{1}+c_{f 2} \cos \theta_{2} \cos \emptyset_{2}+c_{r} \cos \theta_{3} \cos \emptyset_{3}\right) \dot{x}_{b}+\left(k_{f 1} \cos \theta_{1} \cos \emptyset_{1}+k_{f 2} \cos \theta_{2} \cos \emptyset_{2}+\right.$ $\left.k_{r} \cos \theta_{3} \cos \emptyset_{3}\right) x_{b}-\left(c_{f 1} l_{f} \cos ^{2} \emptyset_{1}+c_{f 2} l_{f} \cos ^{2} \emptyset_{2}-c_{r} l_{r} \cos ^{2} \emptyset_{3}\right) \dot{\theta}_{b y}-\left(k_{f 1} l_{f} \cos ^{2} \emptyset_{1}+\right.$ $\left.k_{f 2} l_{f} \cos ^{2} \emptyset_{2}-k_{r} l_{r} \cos ^{2} \emptyset_{3}\right) \theta_{b y}=F_{12 y 1}+F_{12 y 2}$ 

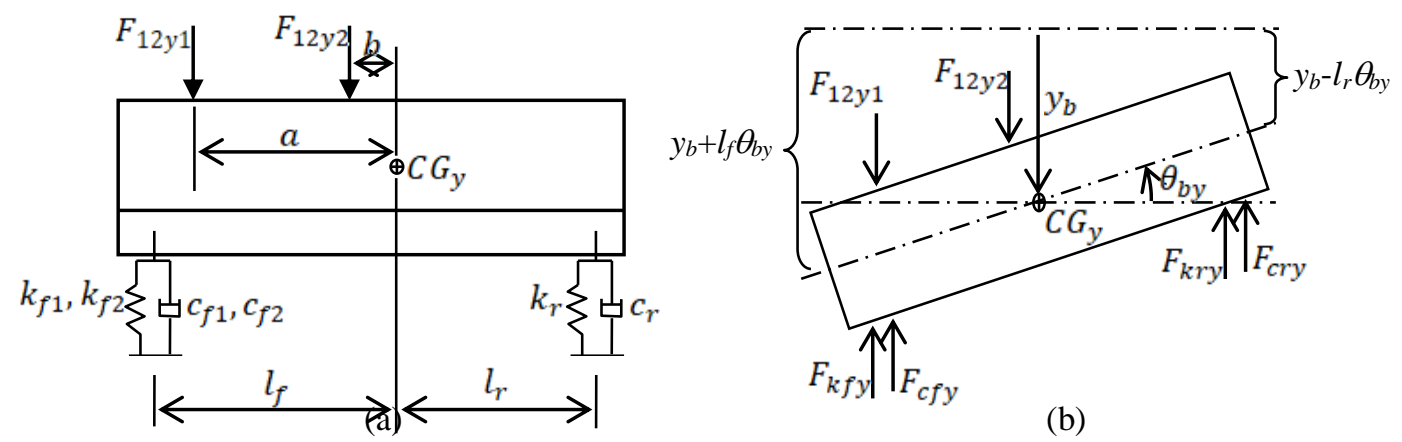

(b)

\section{Gambar 4. (a) Model Matematika, (b) Diagram Benda Bebas Blok Mesin Dalam Arah Vertikal} (Sumbu Y)

Persamaan gerak rotasi terhadap sumbu X blok mesin adalah :

$\sum M_{G y}=J_{G y} \ddot{\theta}_{b y}$

$I_{G y} \ddot{\theta}_{b y}-\left(c_{f 1} l_{f}^{2} \cos ^{2} \emptyset_{1}+c_{f 2} l_{f}^{2} \cos ^{2} \emptyset_{2}+c_{r} l_{r}^{2} \cos ^{2} \emptyset_{3}\right) \dot{\theta}_{b y}+\left(c_{f 1} l_{f} \cos ^{2} \emptyset_{1}+c_{f 2} l_{f} \cos ^{2} \emptyset_{2}-\right.$ $\left.c_{r} l_{r} \cos ^{2} \emptyset_{3}\right) \dot{y}_{b}+\left(c_{f 1} l_{f} \cos \theta_{1} \cos \emptyset_{1}+c_{f 2} l_{f} \cos \theta_{2} \cos \emptyset_{2}-c_{r} l_{r} \cos \theta_{3} \cos \emptyset_{3}\right) \dot{x}_{b}-$

$\left(k_{f 1} l_{f}^{2} \cos ^{2} \emptyset_{1}+k_{f 2} l_{f}^{2} \cos ^{2} \emptyset_{2}+k_{r} l_{r}^{2} \cos ^{2} \emptyset_{3}\right) \theta_{b y}+\left(k_{f 1} l_{f} \cos ^{2} \emptyset_{1}+k_{f 2} l_{f} \cos ^{2} \emptyset_{2}-\right.$

$\left.k_{r} l_{r} \cos ^{2} \emptyset_{3}\right) y_{b}+\left(k_{f 1} l_{f} \cos \theta_{1} \cos \emptyset_{1}+k_{f 2} l_{f} \cos \theta_{2} \cos \emptyset_{2}-k_{r} l_{r} \cos \theta_{3} \cos \emptyset_{3}\right) x_{b}=F_{12 y 1} a+F_{12 y 2} b$

Persamaan gerak blok mesin dalam arah horisontal (sumbu X) diturunkan dari diagram benda bebas seperti ditunjukkan pada gambar 5.

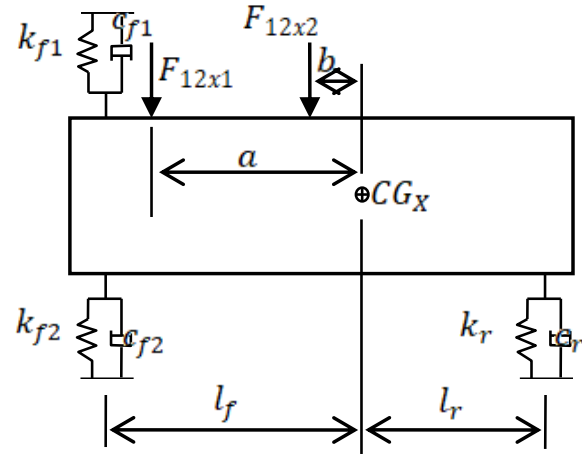

(a)

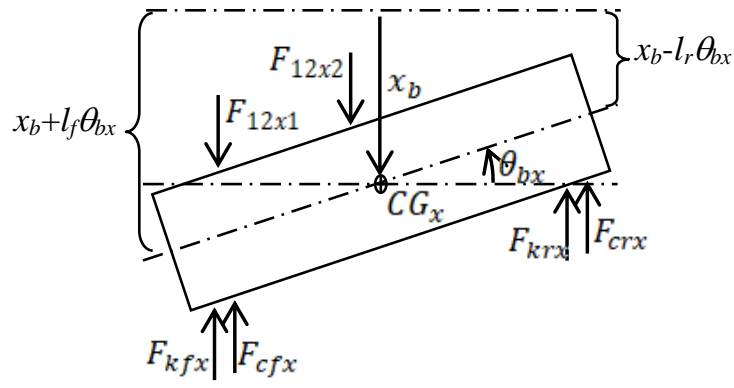

(b)

Gambar 5. (a) Model Matematika, (b) Diagram Benda Bebas Blok Mesin Dalam Arah Horisontal (Sumbu X)

Persamaan gerak translasi horisontal blok mesin adalah :

$\sum \mathrm{F}_{\mathrm{x}}=\mathrm{m} \ddot{\mathrm{x}}_{\mathrm{b}}$

$m \ddot{x}_{b}+\left(c_{f 1} \cos ^{2} \theta_{1}+c_{f 2} \cos ^{2} \theta_{2}+c_{r} \cos ^{2} \theta_{3}\right) \dot{x}_{b}+\left(k_{f 1} \cos ^{2} \theta_{1}+k_{f 2} \cos ^{2} \theta_{2}+k_{r} \cos ^{2} \theta_{3}\right) x_{b}+$

$\left(c_{f 1} \cos \theta \emptyset_{1} \cos \theta_{1}+c_{f 2} \cos \emptyset_{2} \cos \theta_{2}+c_{r} \cos \emptyset_{3} \cos \theta_{3}\right) \dot{y}_{b}+\left(k_{f 1} \cos \emptyset_{1} \cos \theta_{1}+k_{f 2} \cos \emptyset_{2} \cos \theta_{2}+\right.$ $\left.k_{r} \cos \emptyset_{3} \cos \theta_{3}\right) y_{b}-\left(c_{f 1} l_{f} \cos ^{2} \theta_{2}+c_{f 2} l_{f} \cos ^{2} \theta_{2}-c_{r} l_{r} \cos ^{2} \theta_{3}\right) \dot{\theta}_{b x}-\left(k_{f 1} l_{f} \cos ^{2} \theta_{1}+\right.$ $\left.k_{f 2} l_{f} \cos ^{2} \theta_{2}-k_{r} l_{r} \cos ^{2} \theta_{3}\right) \theta_{b x}=F_{12 \times 1}+F_{12 x 2}$

Persamaan gerak rotasi terhadap sumbu Y blok mesin adalah :

$\sum M_{G x}=J_{G x} \ddot{\theta}_{b x}$ 
$I_{G x} \ddot{\theta}_{b x}-\left(c_{f 1} l_{f}^{2} \cos ^{2} \theta_{1}+c_{f 2} l_{f}^{2} \cos ^{2} \theta_{2}+c_{r} l_{r}{ }^{2} \cos ^{2} \theta_{3}\right) \dot{\theta}_{b x}+\left(c_{f 1} l_{f} \cos ^{2} \theta_{1}+c_{f 2} l_{f} \cos ^{2} \theta_{2}-\right.$ $\left.c_{r} l_{r} \cos ^{2} \theta_{3}\right) \dot{x}_{b}+\left(c_{f 1} l_{f} \cos \emptyset_{1} \cos \theta_{1}+c_{f 2} l_{f} \cos \emptyset_{2} \cos \theta_{2}-c_{r} l_{r} \cos \emptyset_{3} \cos \theta_{3}\right) \dot{y}_{b}-$ $\left(k_{f 1} l_{f}^{2} \cos ^{2} \theta_{1}+k_{f 2} l_{f}^{2} \cos ^{2} \theta_{2}+k_{r} l_{r}{ }^{2} \cos ^{2} \theta_{3}\right) \theta_{b x}+\left(k_{f 1} l_{f} \cos ^{2} \theta_{1}+k_{f 2} l_{f} \cos ^{2} \theta_{2}-\right.$ $\left.k_{r} l_{r} \cos ^{2} \theta_{3}\right) x_{b}+\left(k_{f 1} l_{f} \cos \emptyset_{1} \cos \theta_{1}+k_{f 2} l_{f} \cos \emptyset_{2} \cos \theta_{2}-k_{r} l_{r} \cos \emptyset_{3} \cos \theta_{3}\right) y_{b}=F_{12 x 1} a+F_{12 x 2} b$

Persamaan gerak rotasi blok mesin terhadap sumbu $\mathrm{Z}$ diturunkan dari diagram benda bebas seperti ditunjukkan pada gambar 6. Persamaan gerak rotasi terhadap sumbu Z blok mesin adalah :

$\sum M_{G z}=J_{G z} \ddot{\theta}_{b z}$

$T_{12}-\left(k_{f 1} l_{l} \cos ^{2} \emptyset_{1}-k_{f 2} l_{r} \cos ^{2} \emptyset_{2}\right) y_{b}-\left(c_{f 1} l_{l} \cos ^{2} \emptyset_{1}-c_{f 2} l_{r} \cos ^{2} \emptyset_{2}\right) \dot{y}_{b}-\left(k_{f 1} l_{l} \cos \theta_{1} \cos \emptyset_{1}-\right.$ $\left.k_{f 2} l_{r} \cos \theta_{2} \cos \emptyset_{2}\right) x_{b}-\left(c_{f 1} l_{l} \cos \theta_{1} \cos \emptyset_{1}-c_{f 2} l_{r} \cos \theta_{2} \cos \emptyset_{2}\right) \dot{x}_{b}-\left(k_{f 1} l_{l}^{2} \cos ^{2} \emptyset_{1}+\right.$ $\left.k_{f 2} l_{r}^{2} \cos ^{2} \emptyset_{2}\right) \theta_{b z}-\left(c_{f 1} l_{l}^{2} \cos ^{2} \emptyset_{1}+c_{f 2} l_{r}^{2} \cos ^{2} \emptyset_{2}\right) \dot{\theta}_{b z}=J_{G z} \ddot{\theta}_{b z}$

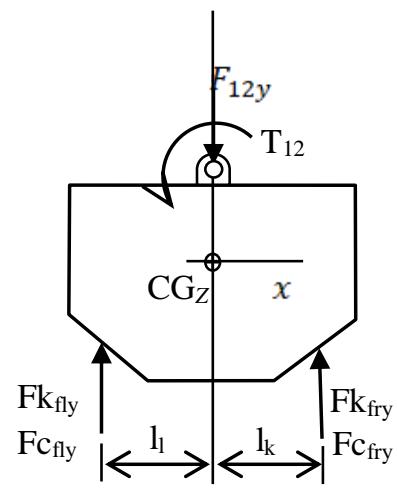

(a)

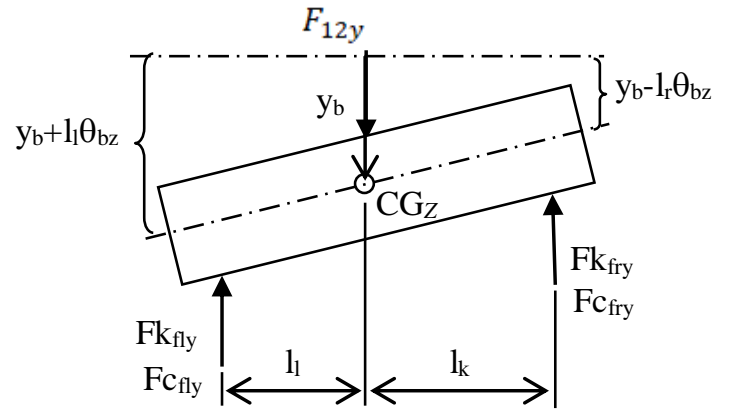

(b)

Gambar 6. (a) Model Matematika, (b) Diagram Benda Bebas Blok Mesin Dalam Arah Rotasi Terhadap Sumbu Z

\subsection{Persamaan State Variable}

Persamaan state variable untuk gerak blok mesin di atas adalah sebagai berikut.

$$
\begin{aligned}
& \left\{\begin{array}{c}
\dot{y}_{b} \\
\dot{v}_{b y} \\
\dot{\theta}_{b y} \\
\dot{\omega}_{b y} \\
\dot{x}_{b} \\
\dot{v}_{b x} \\
\dot{\theta}_{b x} \\
\dot{\omega}_{b x} \\
\dot{\theta}_{b z} \\
\dot{\omega}_{b z}
\end{array}\right\}=\left[\begin{array}{cccccccccc}
0 & 1 & 0 & 0 & 0 & 0 & 0 & 0 & 0 & 0 \\
-A & -B & C & D & -E & -F & 0 & 0 & 0 & 0 \\
0 & 0 & 0 & 1 & 0 & 0 & 0 & 0 & 0 & 0 \\
-G & -H & K & L & -M & -N & 0 & 0 & 0 & 0 \\
0 & 0 & 0 & 0 & 0 & 1 & 0 & 0 & 0 & 0 \\
-P & -Q & 0 & 0 & -R & -S & U & W & 0 & 0 \\
0 & 0 & 0 & 0 & 0 & 0 & 0 & 1 & 0 & 0 \\
-Z & -A A & 0 & 0 & -B B & -C C & D D & E E & 0 & 0 \\
0 & 0 & 0 & 0 & 0 & 0 & 0 & 0 & 0 & 1 \\
-F F & -G G & 0 & 0 & -H H & -K K & 0 & 0 & -L L & -M M
\end{array}\right]\left\{\begin{array}{c}
y_{b} \\
v_{b y} \\
\theta_{b y} \\
\omega_{b y} \\
x_{b} \\
v_{b x} \\
\theta_{b x} \\
\omega_{b x} \\
\theta_{b z} \\
\omega_{b z}
\end{array}\right\}+ \\
& {\left[\begin{array}{ccccc}
0 & 0 & 0 & 0 & 0 \\
\frac{1}{m} & \frac{1}{m} & 0 & 0 & 0 \\
0 & 0 & 0 & 0 & 0 \\
\frac{a}{J_{G y}} & \frac{b}{J_{G y}} & 0 & 0 & 0 \\
0 & 0 & 0 & 0 & 0 \\
0 & 0 & \frac{1}{m} & \frac{1}{m} & 0 \\
0 & 0 & 0 & 0 & 0 \\
0 & 0 & \frac{a}{J_{G x}} & \frac{b}{J_{G x}} & 0 \\
0 & 0 & 0 & 0 & 0 \\
0 & 0 & 0 & 0 & \frac{1}{J_{G z}}
\end{array}\right]\left\{\begin{array}{c}
F_{1 y}^{\prime} \\
F_{2 y}^{\prime} \\
F_{1 x}^{\prime} \\
F_{2 x}^{\prime} \\
T_{12}
\end{array}\right\}}
\end{aligned}
$$


dimana :

$$
\begin{aligned}
& A=\frac{\left(k_{f 1} \cos ^{2} \emptyset_{1}+k_{f 2} \cos ^{2} \emptyset_{2}+k_{r} \cos ^{2} \emptyset_{3}\right)}{m} \\
& B=\frac{\left(c_{f 1} \cos ^{2} \emptyset_{1}+c_{f 2} \cos \emptyset_{2}+c_{r} \cos ^{2} \emptyset_{3}\right)}{m} \\
& C=\frac{\left(k_{f 1} l_{f} \cos ^{2} \emptyset_{1}+k_{f 2} l_{f} \cos ^{2} \emptyset_{2}-k_{r} l_{r} \cos ^{2} \emptyset_{3}\right)}{m} \\
& D=\frac{\left(c_{f 1} l_{f} \cos ^{2} \emptyset_{1}+c_{f 2} l_{f} \cos ^{2} \emptyset_{2}-c_{r} l_{r} \cos ^{2} \emptyset_{3}\right)}{m} \\
& E=\frac{\left(k_{f 1} \cos \theta_{1} \cos \emptyset_{1}+k_{f 2} \cos \theta_{2} \cos \emptyset_{2}+k_{r} \cos \theta_{3} \cos \emptyset_{3}\right)}{m} \\
& F=\frac{\left(c_{f 1} \cos \theta_{1} \cos \emptyset_{1}+c_{f 2} \cos \theta_{2} \cos \emptyset_{2}+c_{r} \cos \theta_{3} \cos \emptyset_{3}\right)}{m} \\
& G=\frac{\left(k_{f 1} l_{f} \cos ^{2} \emptyset_{1}+k_{f 2} l_{f} \cos ^{2} \emptyset_{2}-k_{r} l_{r} \cos ^{2} \emptyset_{3}\right)}{J_{G y}} \\
& H=\frac{\left(c_{f 1} l_{f} \cos ^{2} \emptyset_{1}+c_{f 2} l_{f} \cos ^{2} \emptyset_{2}-c_{r} l_{r} \cos ^{2} \emptyset_{3}\right)}{J_{G y}} \\
& K=\frac{\left(k_{f 1} l_{f}^{2} \cos ^{2} \emptyset_{1}+k_{f 2} l_{f}^{2} \cos ^{2} \emptyset_{2}+k_{r} l_{r}^{2} \cos ^{2} \emptyset_{3}\right)}{J_{G y}} \\
& L=\frac{\left(c_{f 1} l_{f}^{2} \cos ^{2} \emptyset_{1}+c_{f 2} l_{f}^{2} \cos ^{2} \emptyset_{2}+c_{r} l_{r}^{2} \cos ^{2} \emptyset_{3}\right)}{J_{G y}} \\
& M=\frac{\left(k_{f 1} l_{f} \cos \theta_{1} \cos \emptyset_{1}+k_{f 2} l_{f} \cos \theta_{2} \cos \emptyset_{2}-k_{r} l_{r} \cos \theta_{3} \cos \emptyset_{3}\right)}{J_{G y}} \\
& N=\frac{\left(c_{f 1} l_{f} \cos \theta_{1} \cos \emptyset_{1}+c_{f 2} l_{f} \cos \theta_{2} \cos \emptyset_{2}-c_{r} l_{r} \cos \theta_{3} \cos \emptyset_{3}\right)}{J_{G y}} \\
& P=\frac{\left(k_{f 1} \cos \emptyset_{1} \cos \theta_{1}+k_{f 2} \cos \emptyset_{2} \cos \theta_{2}+k_{r} \cos \emptyset_{3} \cos \theta_{3}\right)}{m} \\
& Q=\frac{\left(c_{f 1} \cos \theta \emptyset_{1} \cos \theta_{1}+c_{f 2} \cos \emptyset_{2} \cos \theta_{2}+c_{r} \cos \emptyset_{3} \cos \theta_{3}\right)}{m} \\
& R=\frac{\left(k_{f 1} \cos ^{2} \theta_{1}+k_{f 2} \cos ^{2} \theta_{2}+k_{r} \cos ^{2} \theta_{3}\right)}{m} \\
& S=\frac{\left(c_{f 1} \cos ^{2} \theta_{1}+c_{f 2} \cos ^{2} \theta_{2}+c_{r} \cos ^{2} \theta_{3}\right)}{m} \\
& U=\frac{\left(k_{f 1} l_{f} \cos ^{2} \theta_{1}-k_{f 2} l_{f} \cos ^{2} \theta_{2}+k_{r} l_{r} \cos ^{2} \theta_{3}\right)}{m} \\
& W=\frac{\left(c_{f 1} l_{f} \cos ^{2} \theta_{2}+c_{f 2} l_{f} \cos ^{2} \theta_{2}-c_{r} l_{r} \cos ^{2} \theta_{3}\right)}{m} \\
& Z=\frac{\left(k_{f 1} l_{f} \cos \emptyset_{1} \cos \theta_{1}+k_{f 2} l_{f} \cos \emptyset_{2} \cos \theta_{2}-k_{r} l_{r} \cos \emptyset_{3} \cos \theta_{3}\right)}{J_{G x}} \\
& A A=\frac{\left(c_{f 1} l_{f} \cos \emptyset_{1} \cos \theta_{1}+c_{f 2} l_{f} \cos \emptyset_{2} \cos \theta_{2}-c_{r} l_{r} \cos \emptyset_{3} \cos \theta_{3}\right)}{J_{G x}} \\
& B B=\frac{\left(k_{f 1} l_{f} \cos ^{2} \theta_{1}+k_{f 2} l_{f} \cos ^{2} \theta_{2}-k_{r} l_{r} \cos ^{2} \theta_{3}\right)}{J_{G X}}
\end{aligned}
$$




$$
\begin{aligned}
C C & =\frac{\left(c_{f 1} l_{f} \cos ^{2} \theta_{1}+c_{f 2} l_{f} \cos ^{2} \theta_{2}-c_{r} l_{r} \cos ^{2} \theta_{3}\right)}{J_{G x}} \\
D D & =\frac{\left(k_{f 1} l_{f}^{2} \cos ^{2} \theta_{1}+k_{f 2} l_{f}^{2} \cos ^{2} \theta_{2}+k_{r} l_{r}^{2} \cos ^{2} \theta_{3}\right)}{J_{G x}} \\
E E & =\frac{\left(c_{f 1} l_{f}^{2} \cos ^{2} \theta_{1}+c_{f 2} l_{f}^{2} \cos ^{2} \theta_{2}+c_{r} l_{r}^{2} \cos ^{2} \theta_{3}\right)}{J_{G x}} \\
F F & =\frac{\left(k_{f 1} l_{l} \cos ^{2} \emptyset_{1}-k_{f 2} l_{r} \cos ^{2} \emptyset_{2}\right)}{J_{G z}} \\
G G & =\frac{\left(c_{f 1} l_{l} \cos ^{2} \emptyset_{1}-c_{f 2} l_{r} \cos ^{2} \emptyset_{2}\right)}{J_{G z}} \\
H H & =\frac{\left(k_{f 1} l_{l} \cos \theta_{1} \cos \emptyset_{1}-k_{f 2} l_{r} \cos \theta_{2} \cos \emptyset_{2}\right)}{J_{G z}} \\
K K & =\frac{\left(c_{f 1} l_{l} \cos \theta_{1} \cos \emptyset_{1}-c_{f 2} l_{r} \cos \theta_{2} \cos \emptyset_{2}\right)}{J_{G z}} \\
L L & =\frac{\left(k_{f 1} l_{l}^{2} \cos ^{2} \emptyset_{1}+k_{f 2} l_{r}^{2} \cos ^{2} \emptyset_{2}\right)}{J_{G z}} \\
M M & =\frac{\left(c_{f 1} l_{l}^{2} \cos ^{2} \emptyset_{1}+c_{f 2} l_{r}^{2} \cos ^{2} \emptyset_{2}\right)}{J_{G z}}
\end{aligned}
$$

Diagram blok dibangun berdasarkan persamaan state variable dengan menggunakan software Simulink Matlab. Input parameter-parameter dalam diagram blok diberikan sesuai dengan data-data teknis dari mesin yang diperoleh dari hasil pengukuran, kemudian dilakukan running diagram blok untuk memperoleh respon getaran blok mesin.

\section{HASIL DAN PEMBAHASAN}

Gaya eksitasi pada sistem adalah gaya gas dan gaya inersia pada masing-masing silinder yang diteruskan ke bantalan utama. Gaya gas ditentukan dari grafik tekanan gas hasil pembakaran di dalam silinder terhadap sudut engkol (gambar 7), yaitu dengan mengalikan tekanan gas dengan luas permukaan piston "Mitsubishi Vulcan 550" sebesar 3848,541 $\mathrm{mm}^{2}$.

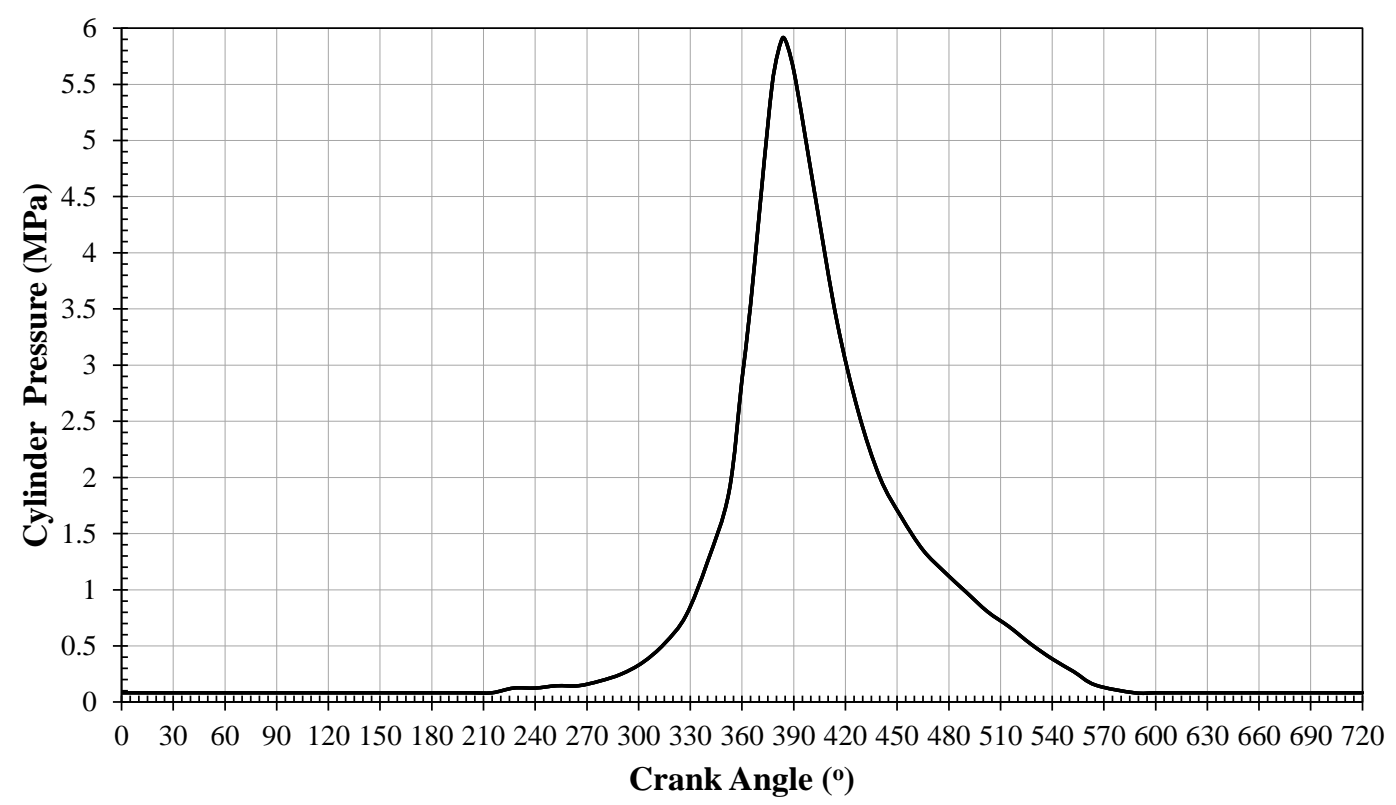

Gambar 7. Grafik Tekanan Gas terhadap Sudut Engkol 
Mesin "Mitsubishi Vulcan 550" mempunyai dua silinder segaris. Besarnya gaya gas di dalam silinder 1 dan 2 pada tiap perubahan sudut engkol diberikan dalam bentuk grafik masing-masing seperti gambar 8, 9 dan 10 untuk posisi dua pistonnya yang membentuk sudut antar engkol $0^{\circ}, 90^{\circ}$ dan $180^{\circ}$.

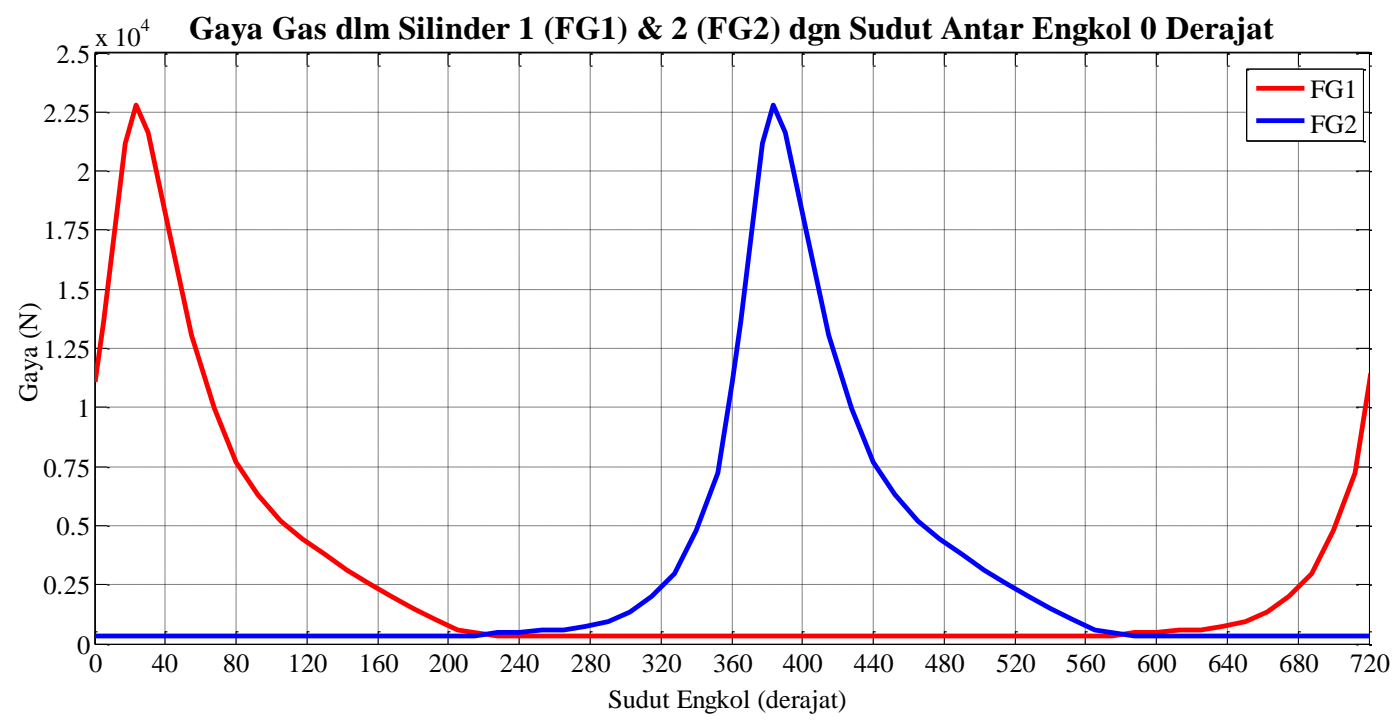

Gambar 8. Grafik Gaya Gas Dalam Silinder 1 dan 2 Dengan Sudut Antar Engkol 0

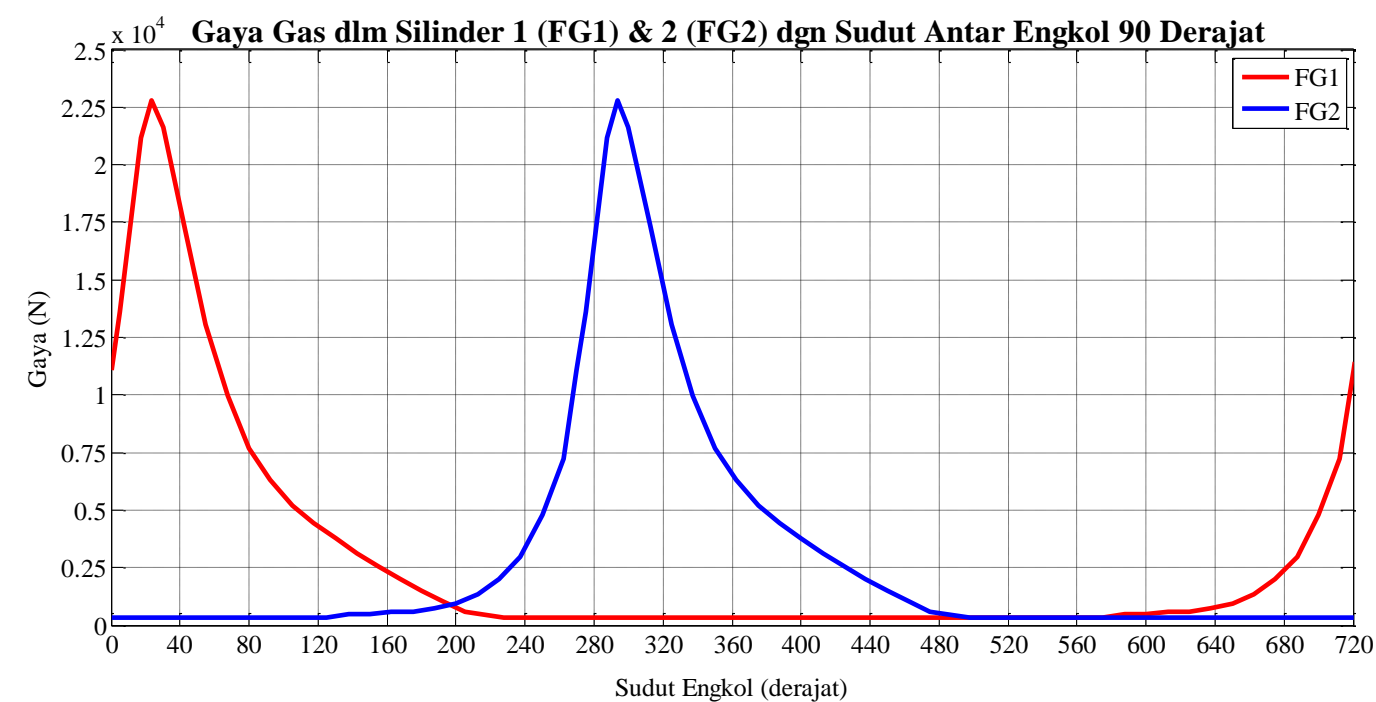

Gambar 9. Grafik Gaya Gas Dalam Silinder 1 Dan 2 Dengan Sudut Antar Engkol 90 


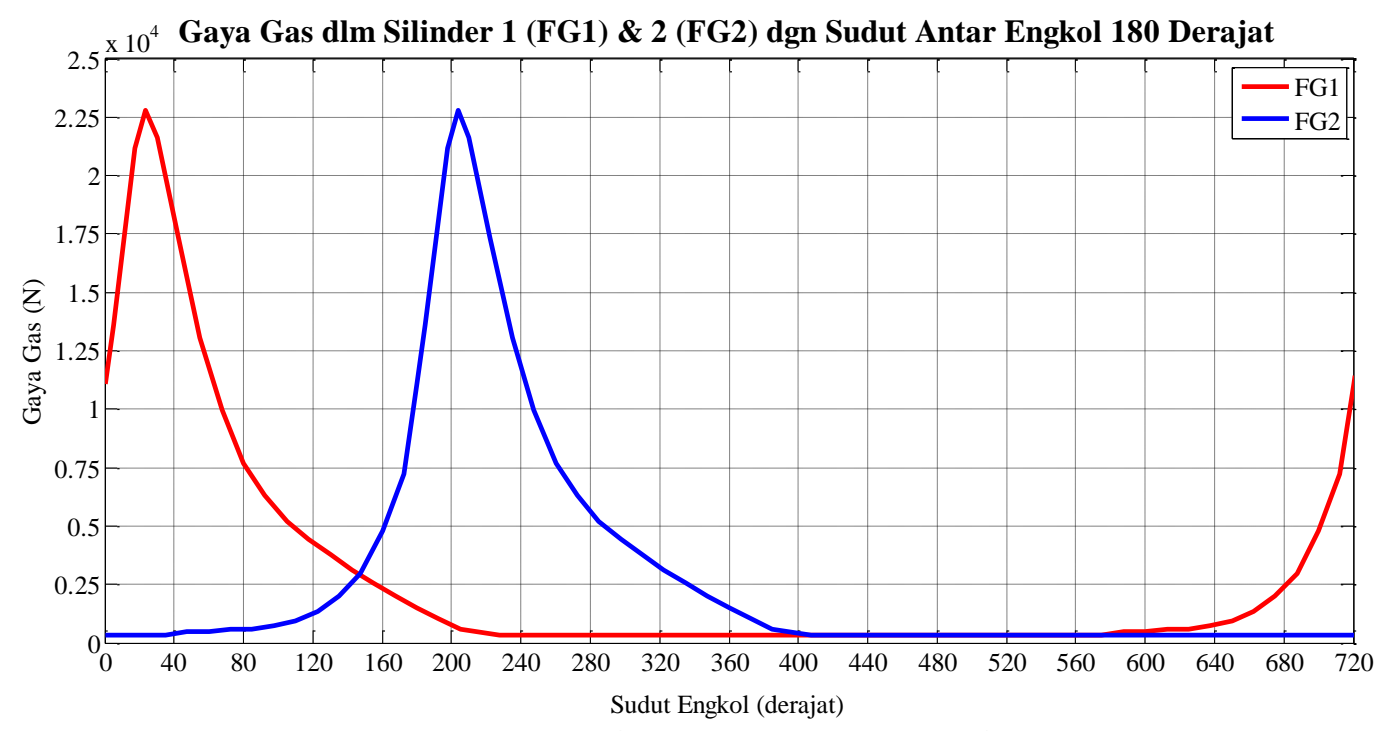

Gambar 10. Grafik Gaya Gas Dalam Silinder 1 dan 2 Dengan Sudut Antar Engkol 180

Bantalan utama menerima gaya akibat gaya gas dan gaya inersia yang besarnya ditentukan dengan persamaan (1). Gaya pada bantalan utama tersebut yang menimbulkan getaran pada blok mesin. Data-data teknis dari mesin "Mitsubishi Vulcan 550" diberikan pada tabel 1 berikut ini.

Tabel 1. Data teknis dari mesin

\begin{tabular}{lcc}
\hline \multicolumn{1}{c}{ Properties } & Simbol & Besar \\
\hline Panjang connecting rod & $\mathrm{l}$ & $0,1150 \mathrm{~m}$ \\
Panjang engkol & $\mathrm{r}$ & $0,0350 \mathrm{~m}$ \\
Jarak titik berat connecting rod ke big end & $\mathrm{l}_{\mathrm{A}}$ & $0,0245 \mathrm{~m}$ \\
Jarak titik berat mesin ke rubber mount depan & $\mathrm{l}_{\mathrm{f}}$ & $0,08 \mathrm{~m}$ \\
Jarak titik berat mesin ke rubber mount belakang & $\mathrm{l}_{\mathrm{r}}$ & $0,45 \mathrm{~m}$ \\
Jarak titik berat mesin ke rubber mount depan kiri & $\mathrm{l}_{\mathrm{l}}$ & $0,20 \mathrm{~m}$ \\
Jarak titik berat mesin ke rubber mount depan kanan & $\mathrm{l}_{\mathrm{k}}$ & $0,12 \mathrm{~m}$ \\
Jarak titik berat mesin ke connecting rod 1 & $\mathrm{a}$ & $0,143 \mathrm{~m}$ \\
Jarak titik berat mesin ke connecting rod 2 & $\mathrm{b}$ & $0,070 \mathrm{~m}$ \\
Massa connecting rod & $\mathrm{m} 3$ & $0,4722 \mathrm{~kg}$ \\
Massa mesin & $\mathrm{m}$ & $90 \mathrm{~kg}$ \\
Massa piston & $\mathrm{m} 4$ & $0,21922 \mathrm{~kg}$ \\
Inersia mesin (sb.X) & $\mathrm{Jgx}$ & $18,225 \mathrm{~kg} \cdot \mathrm{m}^{2}$ \\
Inersia mesin (sb.Y) & $\mathrm{Jgy}$ & $18,225 \mathrm{~kg} \cdot \mathrm{m}^{2}$ \\
Inersia mesin (sb.Z) & $\mathrm{Jgz}$ & $3,6 \mathrm{~kg} \cdot \mathrm{m}^{2}$ \\
\hline
\end{tabular}

Respon getaran blok mesin ditampilkan dalam fungsi waktu. Waktu ditentukan dari persamaan (16) berikut ini.

$t=\frac{\theta x \frac{\pi}{180}}{\frac{2 \pi n}{60}}=\frac{\theta}{6 n}$

dimana : $\theta=$ pergeseran sudut engkol (derajat)

$n=$ putaran mesin $(\mathrm{rpm})$

Respon getaran akibat gaya gas dan gaya inersia ditunjukkan pada gambar 11, 12 dan 13 berikut ini. 


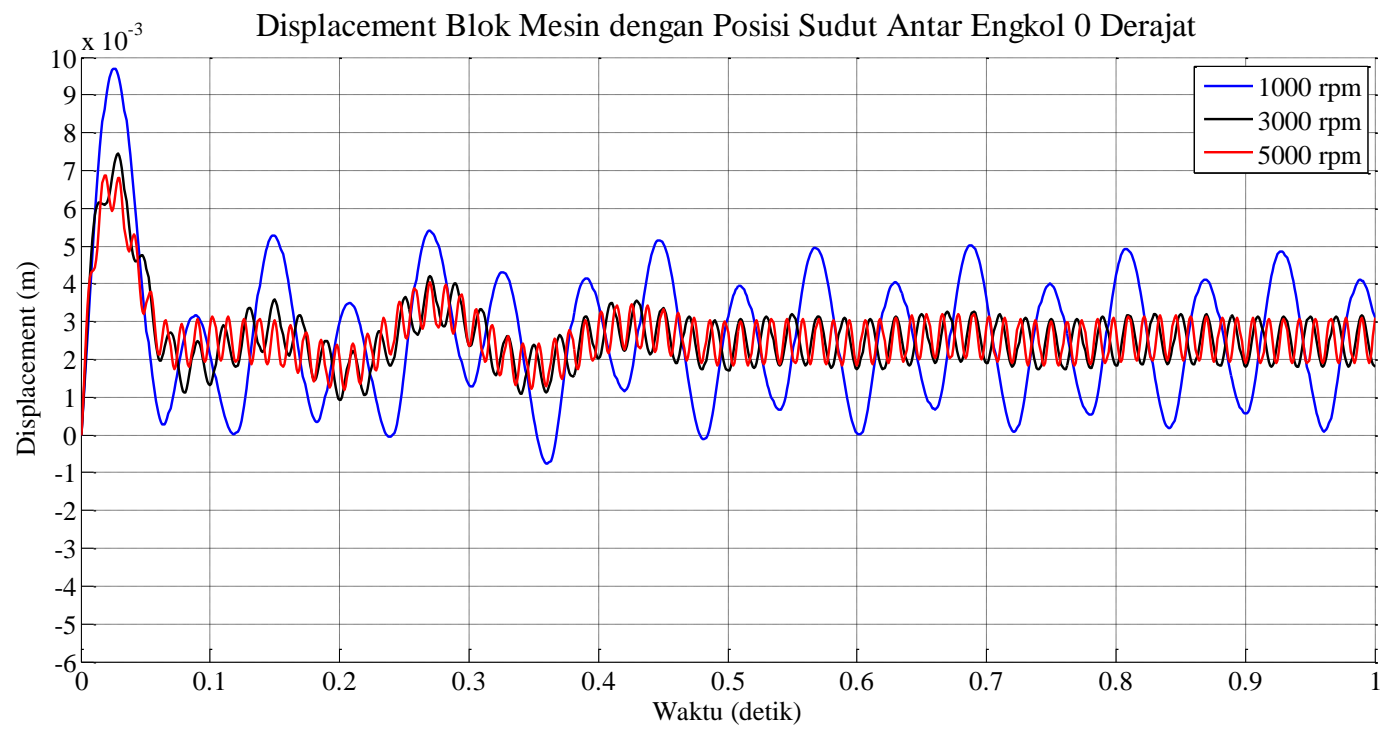

Gambar 11. Displacement Getaran Blok Mesin dengan Posisi Sudut Antar Engkol 0º

Amplitudo getaran blok mesin pada putaran mesin $1000 \mathrm{rpm}$ sebesar $0,002 \mathrm{~m}$ atau $2 \mathrm{~mm}$, untuk posisi sudut antar engkol $0^{\circ}$. Besarnya amplitudo getaran blok mesin hampir sama yaitu $0,0005 \mathrm{~m}$ atau 0,5 $\mathrm{mm}$, pada putaran mesin 3000 dan $5000 \mathrm{rpm}$.

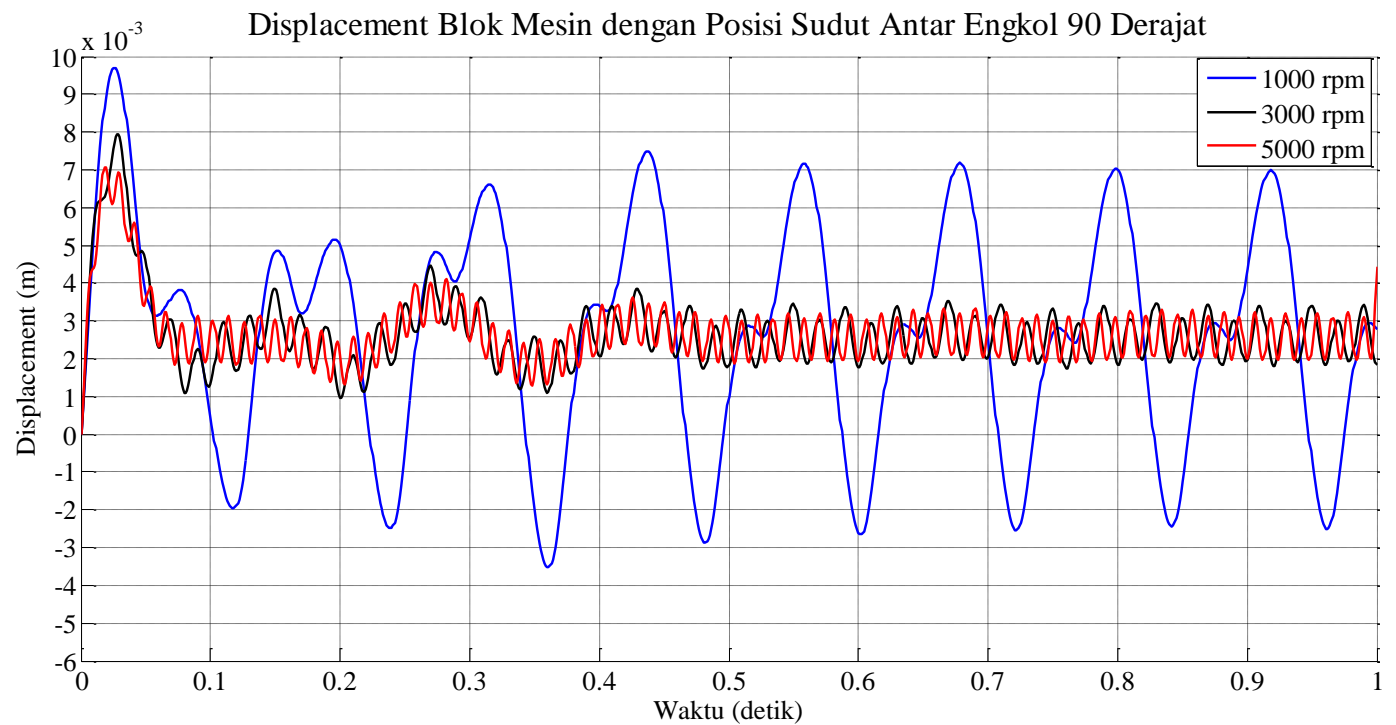

Gambar 12. Displacement Getaran Blok Mesin dengan Posisi Sudut Antar Engkol 90

Amplitudo getaran blok mesin pada putaran mesin $1000 \mathrm{rpm}$ sebesar 0,0045 m atau 4,5 mm, untuk posisi sudut antar engkol $90^{\circ}$. Besarnya amplitudo getaran blok mesin hampir sama yaitu $0,0005 \mathrm{~m}$ atau $0,5 \mathrm{~mm}$, pada putaran mesin 3000 dan $5000 \mathrm{rpm}$. 


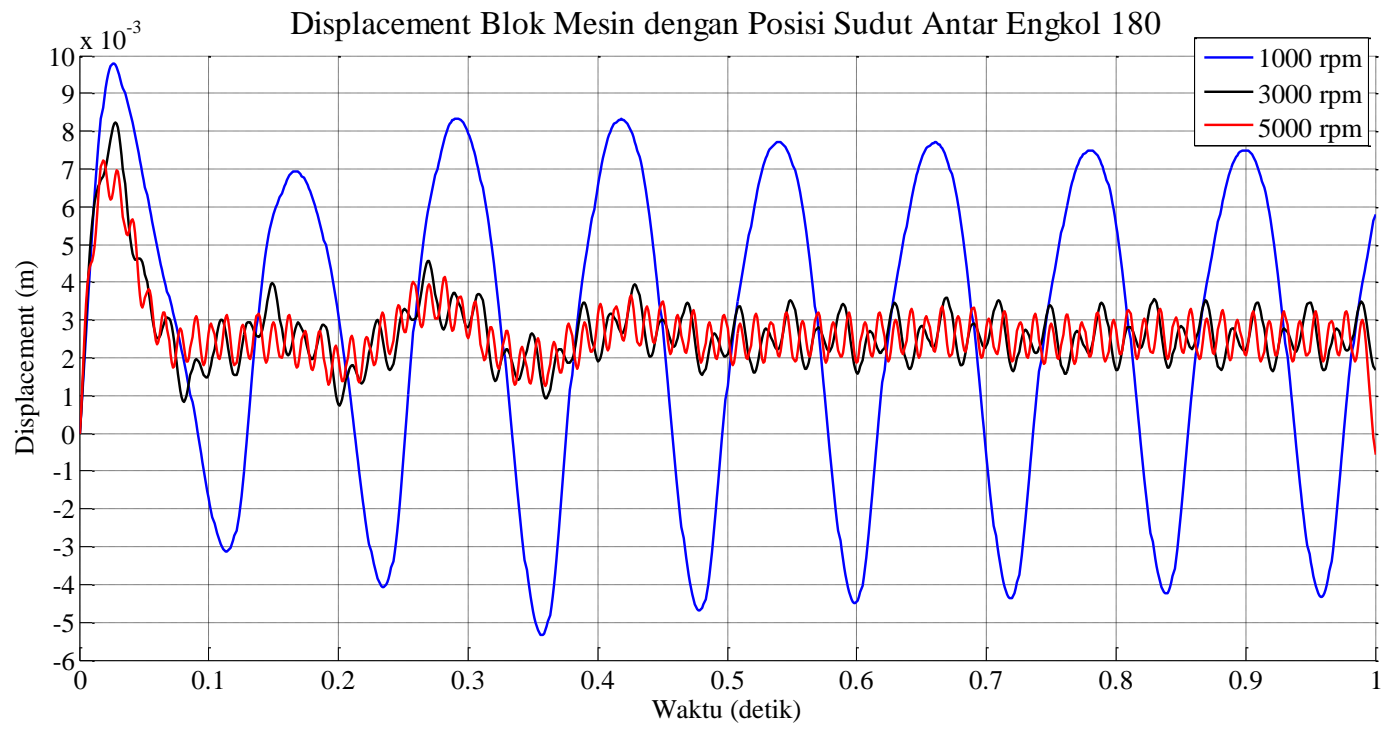

Gambar 13. Simpangan Getaran Blok Mesin dengan Posisi Sudut Antar Engkol 180

Amplitudo getaran blok mesin pada putaran mesin $1000 \mathrm{rpm}$ sebesar 0,0055 m qatau 5,5 mm, untuk posisi sudut antar engkol $180^{\circ}$. Besarnya amplitudo getaran blok mesin hampir sama yaitu $0,0005 \mathrm{~m}$ atau $0,5 \mathrm{~mm}$, pada putaran mesin 3000 dan $5000 \mathrm{rpm}$. Getaran blok mesin paling besar terjadi pada posisi sudut antar engkol $180^{\circ}$ pada putaran mesin $1000 \mathrm{rpm}$, dari ketiga posisi sudut antar engkol tersebut. Getaran blok mesin hampir sama besarnya untuk ketiga posisi sudut antar engkol, pada putaran 3000 dan $5000 \mathrm{rpm}$.

\section{KESIMPULAN}

Getaran yang terjadi pada blok mesin semakin tinggi pada putaran mesin rendah. Hal ini disebabkan karena gaya gas masih mendominasi besarnya gaya yang diterima bantalan utama. Getaran blok mesin semakin kecil pada putaran mesin tinggi. Hal ini disebabkan pada putaran mesin tinggi gaya inersia komponen-komponen yang bergerak lebih dominan diterima bantalan utama. Posisi sudut antar engkol tidak berpengaruh terhadap besarnya getaran blok mesin pada putaran mesin tinggi.

Getaran blok mesin paling besar terjadi pada posisi sudut antar engkol $180^{\circ}$. Hal ini disebabkan karena pada posisi sudut antar engkol $180^{\circ}$ beda fase langkah ekspansi piston 1 dan piston 2 adalah $180^{\circ}$. Beda fase langkah ekspansi piston 1 dan piston 2 adalah $270^{\circ}$ pada posisi sudut antar engkol $90^{\circ}$, sedangkan pada posisi sudut antar engkol $0^{\circ}$ beda fase langkah ekspansi piston 1 dan piston 2 adalah $360^{\circ}$, sehingga semakin dekat beda fase langkah ekspansi kedua piston, semakin besar pula getaran blok mesin yang dihasilkan.

\section{DAFTAR PUSTAKA}

[1] Ramachandran, T., dan Padmanaban, K. P. 2012. "Review on Internal Combustion Engine Vibrations and Mountings". International Journal of Engineering Sciences \& Emerging Technologies. Vol 3. No 1. Hal 63-73.

[2] Park, J. G., Jeong, W. B., Seo, Y. S., dan Yoo, W. S. 2007. "Optimization of Crank Angles to Reduce Excitation Forces and Moments in Engines". Journal of Mechanical Science and Technology. Vol 21. No 2. Hal. 272-281.

[3] Karabulut, H. 2012. "Dynamic Modeling of A Two-Cylinder Four-Stroke Internal Combustion Engine and Vibration Treatment”. International Journal of Engine Research 13 (6). Hal 616-627.

[4] Hoffman, D. M. W., dan Dowling, D. R. 2001. "Fully Coupled Rigid Internal Combustion Engine Dynamics and Vibration - Part I : Model Development". Journal of Engineering for Gas Turbines and Power. Vol 123. Hal. 677-684.

[5] Guzzomi, A. L., Hesterman, D. C., dan Stone, B. J. 2007. "The Effect of Piston Friction on Engine Block Dynamics". Proceedings of The Institution of Mechanical Engineers, Part K : Journal of Multi-body Dynamics. Vol 221. Hal 277-289.

[6] Yu, Y., Naganathan, N. G., dan Dukkipati, R. V. 2001. "A Literature Review of Automotive Vehicle Engine Mounting Systems". Mechanism and Machine Theory 36. Hal 123-142. 